\title{
ON LEAKAGE FROM THE NEAR-SURFACE RADIOACTIVE WASTE STORAGE FACILITY
}

\author{
M. KONSTANTINOVA ${ }^{1}$ \\ A. GUDELIS ${ }^{1}$ \\ D. BUTKUS ${ }^{2}$
}

\author{
${ }^{1}$ Institute of Physics, Nuclear and Environmental \\ Radioactivity Research Laboratory \\ Savanoriu 231, Vilnius LT-02300, Lithuania \\ ${ }^{2}$ Gediminas Technical University \\ Department of Environment Protection \\ Sauletekio, 11, Vilnius LT-01513, Lithuania
}

Received: 09/11/05

Accepted: 29/03/06 *to whom all correspondence should be addressed: e-mail: marina@tvarka.ar.fi.It

\begin{abstract}
Maisiagala RADON type radioactive waste storage facility was commissioned in 1963 in a marshy, ecologically sensitive locality, where soluble radionuclides easily can penetrate and migrate with groundwater. To assure the requirements of radiation safety, the analysis of radionuclide leakage from the radioactive waste storage facility is performed continuously. ${ }^{3} \mathrm{H}$ (tritium, $\mathrm{T}_{1 / 2}=12.33$ years) is of greatest interest in the storage facility reservoir or its surroundings. Liquid scintillation counting (LSC) involving ultra-low level device Quantulus (Wallac) was utilized for quantitative determination of tritium. Elevated ${ }^{3} \mathrm{H}$ concentration (reached $23900 \mathrm{~Bq} \mathrm{I}^{-1}$ ) is observed continuously in the borehole, which is nearest to the radioactive waste reservoir. The average prevailing groundwater flow direction is close to the northern direction. This is the direction of waterlogged lowland, the head of the river, where radionuclides can penetrate. ${ }^{3} \mathrm{H}$ concentration in the borehole located $12 \mathrm{~m}$ further in the prevailing groundwater flow direction, varies from minimum detectable values to $7500 \mathrm{~Bq} \mathrm{l}^{-1}$. MOC3D software was used for modelling ${ }^{3} \mathrm{H}$ transport in groundwater.

For field measurements a portable gamma-spectrometer Inspector-2000 (Canberra) with 20\% relative efficiency HPGe detector (GC2018) was used. The measurements in-situ revealed both qualitative and quantitative variation of gamma-ray intensity at the facility's territory and outside. The remaining contamination by ${ }^{226} \mathrm{Ra}$ was confirmed at the spot at the distance of $\sim 20 \mathrm{~m}$ from the radioactive waste reservoir, ${ }^{226} \mathrm{Ra}$ concentration at the spot reached 106 $\mathrm{Bq} \mathrm{kg}^{-1}$ in $2004 .{ }^{137} \mathrm{Cs}$ concentration in soil does not exceed that in Lithuanian soils after Chernobyl NPP accident.

${ }^{3} \mathrm{H}$ concentration in soil moisture, both on the territory of facility and outside, increases with depth and reached $187 \pm 10 \mathrm{~Bq} \mathrm{I}^{-1}$. ${ }^{3} \mathrm{H}$ concentration in lupine (Lupinus polyphyllus) reached $150 \pm 9 \mathrm{~Bq} \mathrm{l}^{-1}$. It exceeds ${ }^{3} \mathrm{H}$ concentration in grass outside the facility territory by 20-30 times.

The fact that elevated ${ }^{3} \mathrm{H}$ concentration was found not only in groundwater of boreholes on the territory of the storage facility, but in soil moisture and vegetation samples shows that radionuclide leakage from the reservoir occurs and the possibility of leakage can increase over time. The storage facility requires continuous monitoring and management strategy in the nearest future.
\end{abstract}

KEYWORDS: radioactive waste, "RADON" type storage facility, leakage, ${ }^{3} \mathrm{H},{ }^{137} \mathrm{Cs},{ }^{226} \mathrm{Ra}$

\section{INTRODUCTION}

Safe management of radioactive waste is one of the main issues of radioecology in the world. To assure the requirements of radiation safety, the analysis of radionuclide leakage from the radioactive waste storage facility should be performed. The procedure evaluates the change of the system, pathways of radionuclide leakage, and possible impact on humans or the 
environment. To estimate the possible radioactive contamination of the environment it is necessary to research experimentally concentrations of radionuclides in the groundwater or in soil and vegetation; the processes of radionuclide migration must be controlled, analyzed and modeled. This problem requires the permanent perfection of methods, and periodical specification of measurement, if new data appear.

A lot of countries use near-surface radioactive waste storage facilities for storage of low or intermediate level radioactive waste. RADON type facilities were built in the former Soviet Union and some Eastern European countries in the 60-70-ties. According to standard design, all waste was placed into special repositories, which might be concrete vaults or trenches [1]. Mostly, small vaults were divided into compartments with concrete walls, where waste was stored without containers [2]. This type of facility is installed in Lithuania near Maisiagala town about $30 \mathrm{~km}$ from the capital-city Vilnius.

${ }^{3} \mathrm{H}$ (tritium, $\mathrm{T}_{1 / 2}=12.33$ years) is of greatest interest in the storage facility reservoir or its surroundings. Tritium easy goes through the engineering barriers made of concrete, in case of broken hydroisolation [2]. The ${ }^{3} \mathrm{H}$ diffusion coefficient in granite is $15.0 \cdot 10^{-12} \mathrm{~m}^{2} \mathrm{~s}^{-1}$, and in concrete it is $54.9 \cdot 10^{-12} \mathrm{~m}^{2} \mathrm{~s}^{-1}$ [3]. ${ }^{3} \mathrm{H}$ in liquid form is assimilated faster and is 25000 times more dangerous than in gas form [4]. Furthermore, Maisiagala storage facility was constructed in a marshy, ecologically sensitive locality, where soluble radionuclides easily can penetrate and migrate with groundwater.

The aim of this work is to estimate the leakage of radionuclides (especially ${ }^{3} \mathrm{H}$ ) from the reservoir of near-surface (RADON type) radioactive waste storage facility.

\section{OBJECT AND METHODS}

Maisiagala RADON type storage facility was installed in a forest at a distance of $7 \mathrm{~km}$ from Maisiagala town on top of the sandy hill located near waterlogged lowland. This place belongs to the small river Juoda basin. The soil is glacial sediments (sand, pebble, till), thin (up to 10 $\mathrm{m}$ ) layer of fine sand with fragmentary organic sediments (peat). The solid storage facility is a monolithic ferroconcrete reservoir with the $\left(200 \mathrm{~m}^{3}\right)$ useful volume of the reservoir. Since 1989 radioactive waste in the storage facility has not been disposed, and the storage facility was closed. The following radioactive waste was disposed in the reservoir: ${ }^{3} \mathrm{H},{ }^{14} \mathrm{C}{ }^{22} \mathrm{Na},{ }^{36} \mathrm{Cl}$, ${ }^{55} \mathrm{Fe},{ }^{60} \mathrm{Co},{ }^{63} \mathrm{Ni},{ }^{90} \mathrm{Sr}+{ }^{90} \mathrm{Y},{ }^{106} \mathrm{Ru},{ }^{109} \mathrm{Cd},{ }^{125} \mathrm{Sb},{ }^{127} \mathrm{Te},{ }^{133} \mathrm{Ba},{ }^{134} \mathrm{Cs},{ }^{137} \mathrm{Cs},{ }^{144} \mathrm{Ce},{ }^{147} \mathrm{Pm},{ }^{155} \mathrm{Eu}$, ${ }^{170} \mathrm{Tm},{ }^{198} \mathrm{Au},{ }^{204} \mathrm{TI},{ }^{210} \mathrm{Po},{ }^{226} \mathrm{Ra},{ }^{234} \mathrm{U},{ }^{238} \mathrm{U},{ }^{239} \mathrm{Pu}$ and $\mathrm{Pu}-\mathrm{Be}$ neutron source. Calculated total activities of disposed tritium, ${ }^{137} \mathrm{Cs}$, and ${ }^{226}$ Ra were $1.02 \cdot 10^{14} \mathrm{~Bq}, 3.85 \cdot 10^{13} \mathrm{~Bq}$, and $1.10 \cdot 10^{11}$ Bq, respectively, in February 2005.

There are 10 boreholes installed on the storage facility territory for groundwater control (Fig. 1).

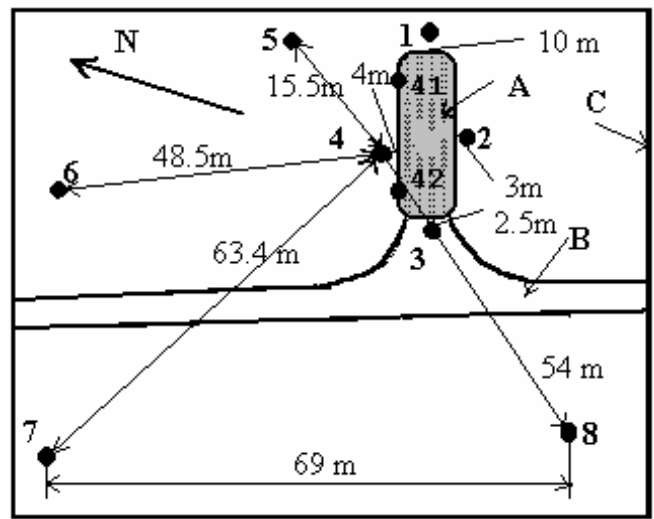

Figure 1. Scheme of distribution of boreholes around the reservoir: $1,2 \ldots 8-$ the number of boreholes, $\mathrm{A}$ - reservoir, $\mathrm{B}$ - asphaltic path, $\mathrm{C}$ - metallic fence

For groundwater sampling a water pump is used (Fig. 2). $20 \mathrm{I}$ of water is sampled from each borehole each time. 


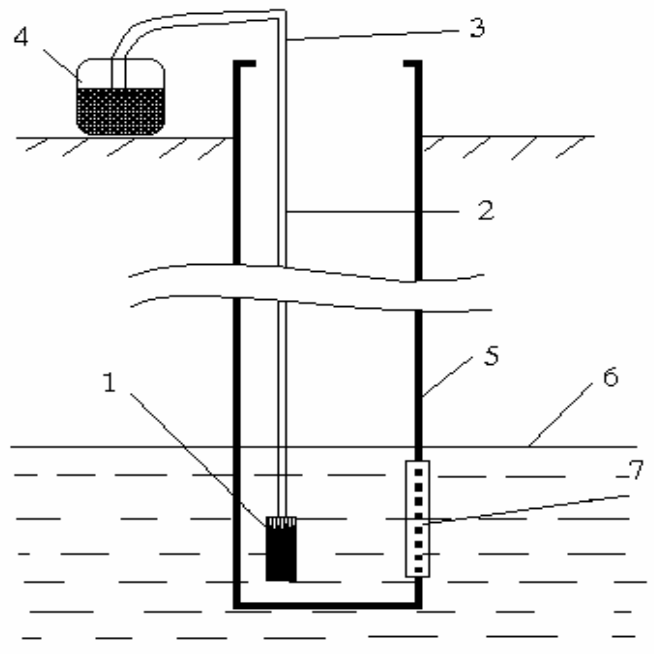

Figure 2. Scheme of water sampling: 1 - water pump, 2 - water sampling pipe, 3 - rope and cable of pump, 4 - vessel, 5 - borehole pipe, 6 - groundwater top, 7 - borehole filter

Liquid scintillation counting (LSC) involving ultra-low level device Quantulus (Wallac) was utilized for quantitative determination of tritium. Prior to measurements a moisture was extracted from the original soil or plants by the distillation procedure. Extracted moisture as well as a groundwater sample was mixed with the commercial cocktail OptiPhase TriSafe (PerkinElmer). The mixing ratio applied was $4 \mathrm{ml}$ of water with $16 \mathrm{ml}$ of scintillation cocktail. For efficiency calibration the tritiated water reference standard solution provided by the IAEA was used. While measuring samples a counting efficiency was corrected for quenching effect by external standard technique. To determine the concentration of gamma-ray emitting radionuclides $\left({ }^{137} \mathrm{Cs},{ }^{226} \mathrm{Ra}\right)$ in soil, the soil is sampled on the territory of the facility and outside, at the depth of $0-5 \mathrm{~cm}$, and in some places at the depth of $50 \mathrm{~cm}$, each $10 \mathrm{~cm}$. The ${ }^{137} \mathrm{Cs}$ activity was determined using a gamma semiconductor $\mathrm{Ge}(\mathrm{Li})$ spectrometer with the counting efficiency of $0.26 \%$, in the 1 I volume Marinelli standard baker.

Additionally, ${ }^{137} \mathrm{Cs}$ and ${ }^{226} \mathrm{Ra}$ concentration in groundwater were measured. Gamma-ray emitters in groundwater were determined after the evaporating 10 I water sample to dryness and measuring the residual by HPGe well-type detector [5]. ${ }^{226} \mathrm{Ra}$ activity was determined by the intensity of its daughters, ${ }^{214} \mathrm{~Pb}$ and ${ }^{214} \mathrm{Bi}$, after 3 weeks necessary for equilibrium condition.

\section{RESULTS AND ANALYSIS}

\section{1. ${ }^{3} \mathrm{H}$ concentration in groundwater}

Elevated ${ }^{3} \mathrm{H}$ concentrations were observed in borehole No.4 (Fig. 1). ${ }^{3} \mathrm{H}$ concentration in this borehole significantly exceeds values measured in other boreholes. This shows continuous leakage of ${ }^{3} \mathrm{H}$ from the reservoir. It varied from 200 to $23900 \mathrm{~Bq} \mathrm{I}^{-1}$ (Fig. 3) during 1995-2004, and the maximum value was noticed in 1998. Variations of tritium leakage can be conditioned by two reasons: variation of groundwater level, which depends on meteorological conditions, and change in permeability of limiting barriers. The latter reason has not been studied completely yet.

${ }^{3} \mathrm{H}$ concentration in borehole No.5, located $12 \mathrm{~m}$ further, varies from minimum detectable values to $7500 \mathrm{~Bq} \mathrm{I}^{-1}$ (Fig. 4). The changing course of ${ }^{3} \mathrm{H}$ concentration in the borehole No.5 is close to variations in the borehole No.4, and probably it is influenced by flow direction. In the other boreholes ${ }^{3} \mathrm{H}$ concentration can be lower than the minimum detectable activity. 


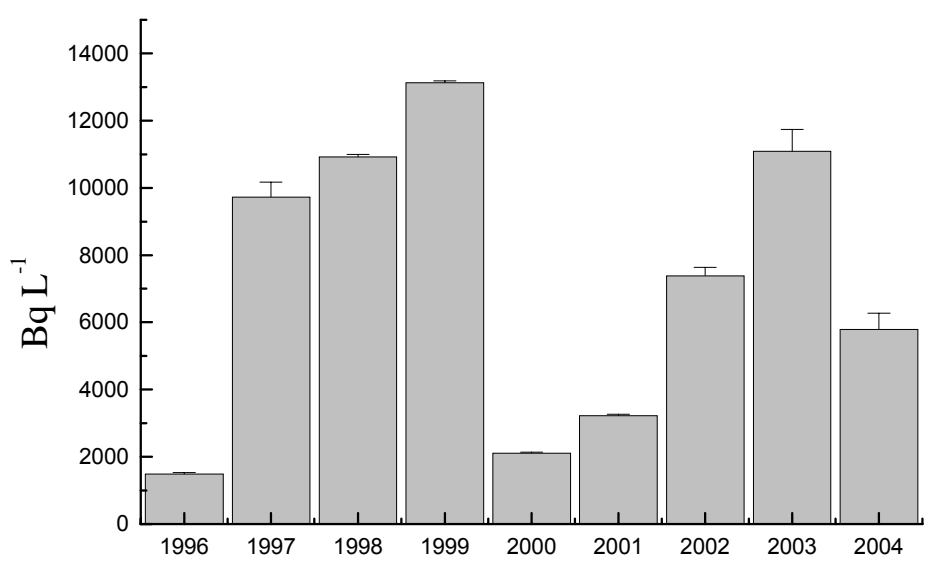

a)

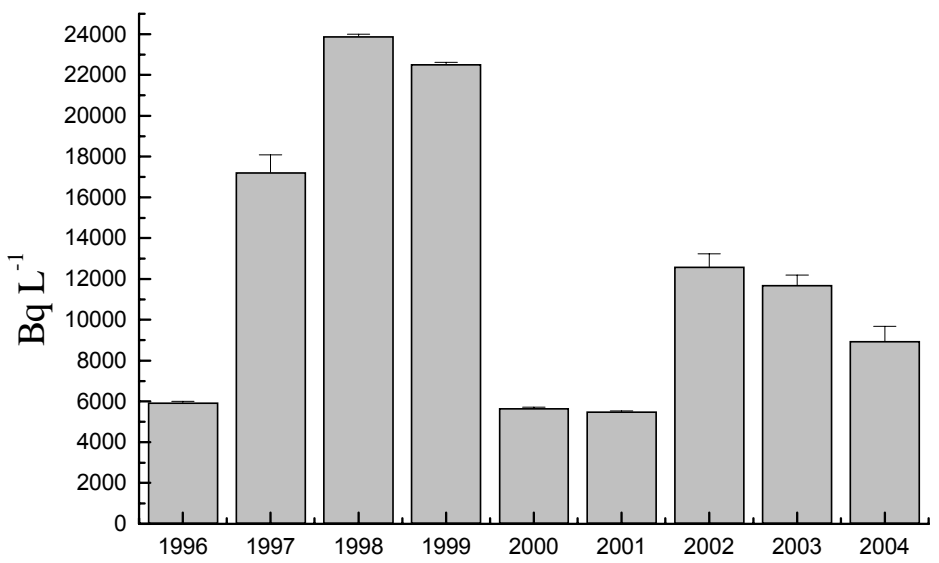

b)

Figure 3. ${ }^{3} \mathrm{H}$ concentration in borehole No. 4: a) average annual concentration, b) maximum annual concentration

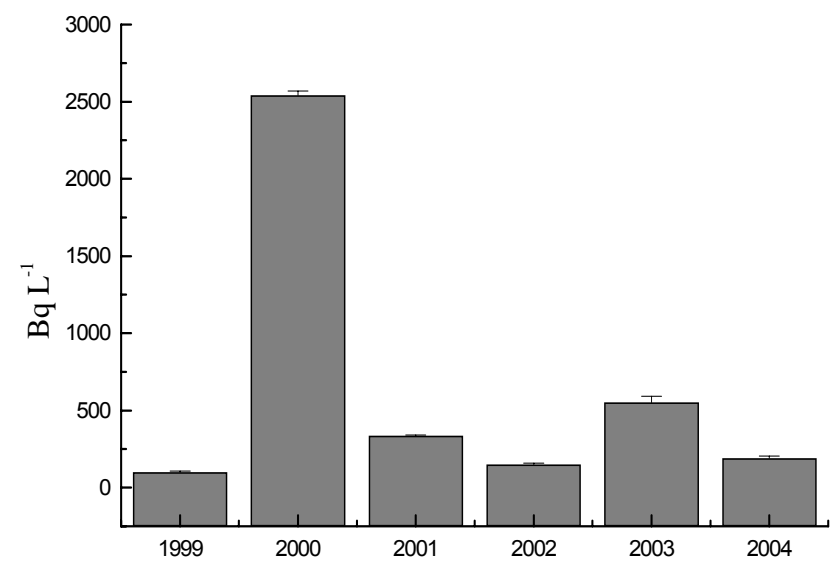

Figure 4. Average annual ${ }^{3} \mathrm{H}$ concentration in borehole No. 5

\subsection{Modelling of ${ }^{3} \mathrm{H}$ transport}

We used software application MOC3D for modelling ${ }^{3} \mathrm{H}$ transport in groundwater.

MOC3D simulates three-dimensional solute transport in flowing groundwater. This model computes change of concentration of solute over time. Solute transport, hydrodynamic dispersion and diffusion, mixing and chemical reactions, as sorption, or decay are considered. 
This transport model is integrated with MODFLOW, a three-dimensional groundwater flow model. The latter calculates groundwater levels, using inside and outside water sources, flow to wells, area recharge, evapotranspiration, flow to drains, flow through river beds etc. $M O C 3 D$ uses the method of characteristics to solve the transport equation on the basis of the hydraulic gradients computed with MODFLOW for a given time step. Two equations are solved. The first is a groundwater flow equation, which describes distribution of water levels in aquifer. The second is a solute transport equation, which calculates concentration of solute in the flowing water system. Using these equations solute concentration in the aquifer over time is calculated. [6].

An initial condition was accepted: contamination with tritium started in 1989 (repository closed). Such parameters were used: half-life of ${ }^{3} \mathrm{H}$ (12,33 years), hydraulic conductivity of head $\left(5 \cdot 10^{-6} \mathrm{~m}^{2} \mathrm{~s}^{-1}\right)$, head thickness $(3 \mathrm{~m})$, recharge $\left(1,4 \cdot 10^{-11} \mathrm{~m} \mathrm{~s}^{-1}\right)$, initial content of tritium $\left(6,9 \cdot 10^{15} \mathrm{~Bq}\right)$, water flow with tritium emission from the repository $\left(3 \cdot 10^{-7} \mathrm{~m}^{3} \mathrm{~s}^{-1}\right)$, longitudinal dispersivity $(0,4 \mathrm{~m})$, transverse dispersivity $(0,2 \mathrm{~m})$, and effective porosity $(0,215)$ [7] .

This programme calculates water levels in the repository's surroundings and ${ }^{3} \mathrm{H}$ transport from the reservoir. Fig. 5 shows water levels near the repository (black square indicates site of the reservoir).

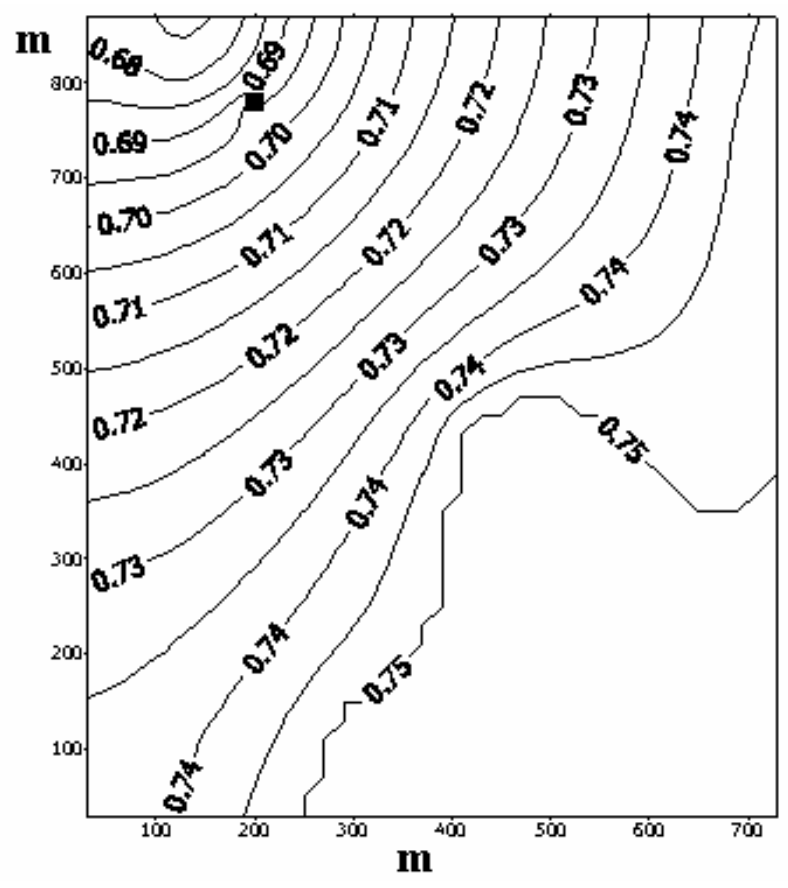

Figure 5. Distribution of water levels in the repository surroundings, $m$ (black square indicates site of reservoir)

Release from the reservoir was estimated according to [2]. Radionuclides released and run out of the reservoir. This equation describes change of activity in the reservoir:

$$
\frac{\mathrm{dQ}}{\mathrm{dt}}=-\left(\lambda_{\mathrm{d}}+\lambda_{\mathrm{L}}\right) \cdot \mathrm{Q}
$$

where $\mathrm{Q}$ is activity of radionuclide, $\mathrm{Bq} ; \lambda_{d}$ and $\lambda_{\mathrm{L}}$ are decay and washout constants comparatively, year $^{-1}$.

$$
\lambda_{\mathrm{L}}=\frac{\mathrm{P}}{\Theta \cdot \mathrm{R} \cdot \mathrm{T}} \mathrm{S},
$$

where $P$ is recharge, $m$ year $^{-1} ; T$ is high of layer above reservoir, $m ; R$ is delay factor (in our case $R=1$, because tritium does not take part in chemical reactions); $\Theta-$ moisture.

$$
\mathrm{R}=1+\frac{\rho_{\mathrm{b}} \cdot \mathrm{K}_{\mathrm{d}}}{\Theta},
$$


where $\rho_{\mathrm{b}}$ is density, $\mathrm{kg} \mathrm{m}^{-3} ; \mathrm{K}_{\mathrm{d}}$ is coefficient of ${ }^{3} \mathrm{H}$ distribution in the reservoir, $\mathrm{m}^{3} \mathrm{~kg}^{-1}$.

Solving equation (5):

$$
\mathrm{Q}(\mathrm{t})=\mathrm{Q}_{0} \cdot \mathrm{e}^{-\left(\lambda_{\mathrm{d}}+\lambda_{\mathrm{L}}\right) \cdot \mathrm{t}},
$$

where $Q_{0}$ is initial activity of radionuclide in the reservoir.

Data of modelling show (Fig. 6) that ${ }^{3} \mathrm{H}$ spreads from the reservoir in the peat-bog direction. Using MOC3D it has been determined that tritium activity concentration decreases with distance from the source while it is comparable to background values at $\sim 500 \mathrm{~m}$ from the reservoir. The model estimates that ${ }^{3} \mathrm{H}$ activity concentration will be about $10000 \mathrm{~Bq} \mathrm{I}^{-1}$ close to the reservoir.

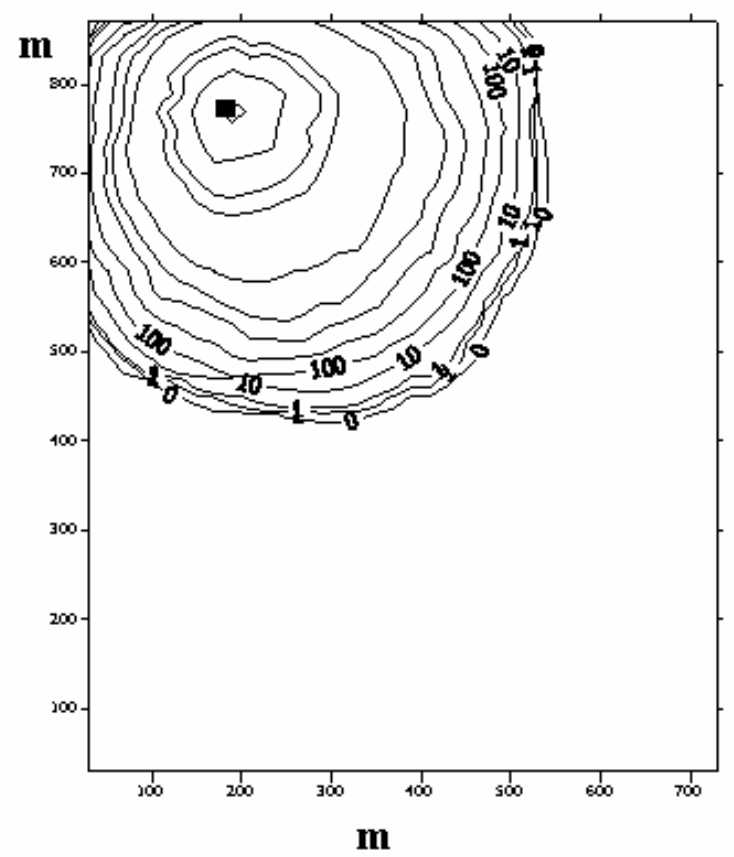

Figure $6 .{ }^{3} \mathrm{H}$ transport expected in the repository surroundings, $\mathrm{Bq}^{-1}$ (black square indicates site of reservoir)

Results of calculation in the sites matched with boreholes N. 4, 5 and 6 are present in Table 1, and compared with resent ${ }^{3} \mathrm{H}$ concentration in groundwater.

Table 1. ${ }^{3} \mathrm{H}$ concentration in boreholes determined and calculated

\begin{tabular}{|c|c|c|}
\hline \multirow{2}{*}{$\begin{array}{c}\text { Number of } \\
\text { borehole }\end{array}$} & \multicolumn{2}{|c|}{ 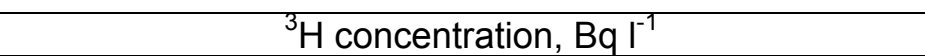 } \\
\hline & Determined 20030627 & Calculated using $M O C 3 D$ \\
\hline 4 & 10980 & 10500 \\
\hline 5 & 1200 & 828 \\
\hline 6 & 2 & 6 \\
\hline
\end{tabular}

The data of Table 1 show rather good coincidence of measured results with theoretical calculations. Although ${ }^{3} \mathrm{H}$ concentration in groundwater near the reservoir is large (borehole 4, partly 5), it distinctly decreases farther from the reservoir. So, after 30 years ${ }^{3} \mathrm{H}$ should not spread far in the repository surroundings.

\section{3. ${ }^{137} \mathrm{Cs}$ and ${ }^{226} \mathrm{Ra}$ concentration in soil and groundwater}

For field measurements a portable gamma-spectrometer Inspector-2000 (Canberra) with 20\% relative efficiency HPGe detector (GC2018) was used. The detector was positioned $1 \mathrm{~m}$ above the ground surface, the measurement time was $1000 \mathrm{~s}$. The measurements in-situ 
revealed both qualitative and quantitative variation of gamma-ray intensity on the facility's territory and outside. The remaining contamination by ${ }^{226} \mathrm{Ra}$ at the spot was confirmed, however higher levels of globally distributed ${ }^{137} \mathrm{Cs}$ were found outside the territory in the forest.

The elevated gamma intensity (300 times higher than the average over the whole territory) place of $\sim 36 \mathrm{~m}^{2}$ area was found in 1994 at the distance of $\sim 20 \mathrm{~m}$ from the reservoir. It was decided that the contamination occurred in 1970-1972, and it was determined that the area was polluted with ${ }^{226} \mathrm{Ra}$. The surface ground layer was gathered up and taken out to facilities of Ignalina NPP. However, ${ }^{226} \mathrm{Ra}$ at the spot concentration reached $106 \mathrm{~Bq} \mathrm{~kg}^{-1}$ in 2004 . It is 5 times higher than typical concentration of Lithuanian soils (from 11 to $68 \mathrm{~Bq} \mathrm{~kg}^{-1}$ ) [8].

${ }^{137} \mathrm{Cs}$ concentration in soil does not exceed that in Lithuanian soils after the Chernobyl NPP accident [9]. The vertical profile shows that this area was contaminated with "global" ${ }^{137} \mathrm{Cs}$ [10].

The maximum ${ }^{137} \mathrm{Cs}$ concentration in groundwater was observed in boreholes No. 2, 4 and 8. The maximum ${ }^{226} \mathrm{Ra}$ concentration was in boreholes No. 2, 4, and 5. However, this value was often below the minimum detectable activity. ${ }^{137} \mathrm{Cs}$ and ${ }^{226} \mathrm{Ra}$ concentration in groundwater reached 0.10 and $0.49 \mathrm{~Bq} \mathrm{I}^{-1}$, respectively.

\section{4. ${ }^{3} \mathrm{H}$ concentration in groundwater, soil and vegetation}

${ }^{3} \mathrm{H}$ concentration in groundwater, soil and vegetation is used to estimate radionuclide leakage. It has been measured in soil moisture in 5 cores at the depths from the surface down to 50 $\mathrm{cm}$. One sampling site (1) was selected near the reservoir (at the borehole No. 1) while the another (2) was outside the facility, in waterlogged lowland. The maximum ${ }^{3} \mathrm{H}$ concentration at the site (1) was observed at the depth of $40-50 \mathrm{~cm}\left(187 \pm 10 \mathrm{~Bq} \mathrm{I}^{-1}\right)$. The maximum ${ }^{3} \mathrm{H}$ concentration at the site (2) was at the depth of $20-30 \mathrm{~cm}\left(161 \pm 9 \mathrm{~Bq} \mathrm{l}^{-1}\right)$. At both sites ${ }^{3} \mathrm{H}$ concentration increased with the depth (Fig. 7). That happens because it gets into the soil with groundwater, and the difference can be explained by variation of the levels of groundwater.

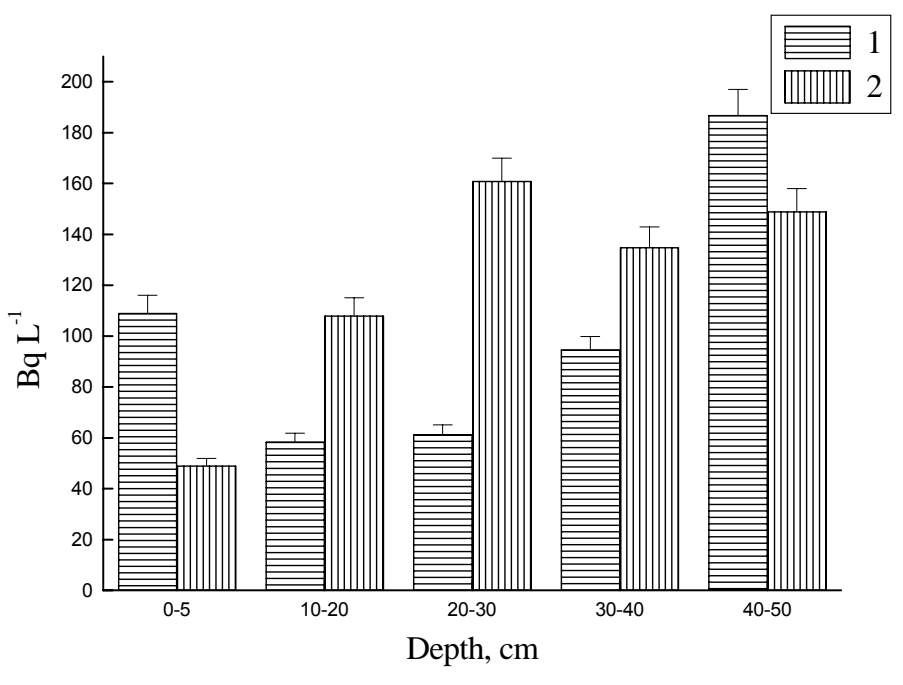

Figure 7. Comparison of ${ }^{3} \mathrm{H}$ concentration in soil moisture, 1 is the site in the territory of the storage facility, 2 is the site outside the facility (maximum concentration in 2003)

Elevated ${ }^{3} \mathrm{H}$ concentration was observed in lupine samples (Lupinus polyphyllus). In $2003,{ }^{3} \mathrm{H}$ concentration in lupine near the reservoir was $150 \pm 9 \mathrm{~Bq}^{-1}$, and outside the territory it was $88 \pm 5 \mathrm{~Bq}^{-1}$. It exceeds ${ }^{3} \mathrm{H}$ concentration in grass measured in the same time outside the facility territory by 20-30 times.

The fact that ${ }^{3} \mathrm{H}$ is found not only in groundwater in the territory of the storage facility, but in soil moisture and vegetation samples confirms radionuclide leakage from the reservoir. 


\section{CONCLUSIONS}

1. Elevated ${ }^{3} \mathrm{H}$ activity concentration (reached $23900 \mathrm{~Bq}^{-1}$ ) was observed continuously in the borehole No.4, which was nearest to the waste reservoir in the prevailing groundwater flow direction. ${ }^{3} \mathrm{H}$ activity concentration in the borehole No.5, located $12 \mathrm{~m}$ farther, varied from minimum detectable values to $7500 \mathrm{~Bq} \mathrm{I}^{-1}$.

2. MOC3D software was used for modelling the ${ }^{3} \mathrm{H}$ transport in groundwater. It was estimated that ${ }^{3} \mathrm{H}$ concentration will be about $10000 \mathrm{~Bq} \mathrm{I}^{-1}$ in the location near the reservoir, and will be comparable to background values at $\sim 500 \mathrm{~m}$ from the reservoir.

3. The remaining contamination by ${ }^{226} \mathrm{Ra}$ at the spot was confirmed, ${ }^{226} \mathrm{Ra}$ activity concentration at the spot has been determined $106 \mathrm{~Bq} \mathrm{~kg}^{-1}$ in 2004 . That value was 5 times larger than typical activity concentration for Lithuanian soils. ${ }^{137} \mathrm{Cs}$ activity concentration in soil does not exceed the characteristic values for Lithuanian soils after the Chernobyl NPP accident.

4. ${ }^{3} \mathrm{H}$ activity concentration in soil moisture, both on the territory of the facility and outside, increased with depth and reached $187 \pm 10 \mathrm{~Bq} \mathrm{I}{ }^{-1}$. ${ }^{3} \mathrm{H}$ activity concentration in lupine (Lupinus polyphyllus) near the reservoir reached $150 \pm 9 \mathrm{~Bq} \mathrm{I}^{-1}$, while outside the territory it was $88 \pm 5 \mathrm{~Bq} \mathrm{I}^{-1}$. It exceeded ${ }^{3} \mathrm{H}$ activity concentration in grass outside the facility territory by $20-30$ times.

5. The fact that ${ }^{3} \mathrm{H}$ was found not only in groundwater of the boreholes in the territory of the storage facility, but also in soil moisture and vegetation samples shows that radionuclide leakage from the reservoir occurs and the possibility of leakage can increase over time. The storage facility requires continuous monitoring and management strategy in the nearest future.

\section{REFERENCES}

1. Prozorov L.B., Tkatchenko A.V., Gouskov A.V. and Korneva S.A. (2001) URL: http://www.wmsym.org/Abstracts/2001/22/22-7.pdf

2. Grigaliūnienè D. (2001) Modelling of radionuclide migration from near-surface radioactive waste repositories, PhD Thesis, University of Kaunas (in Lithuanian).

3. Szántó Zs., Hertelendi E., Molnár M. and Palcsu L. (1998) The interaction of trace levels of ${ }^{3} \mathrm{H},{ }^{99} \mathrm{Tc},{ }^{63} \mathrm{Ni}$, and ${ }^{14} \mathrm{C}$ with granite, concrete, carbonate, chlorite, quartz and Na-bentonite. Annual report, Institute of Nuclear research of the Hungarian Academy of Sciences, 56-58.

4. Parks B. (1997) URL: http://www.sc.doe.gov/sc-80/cap88/tritium.html

5. Gudelis A., Remeikis V., Plukis A. and Lukauskas D. (2000) Efficiency calibration of HPGe detectors for measuring environmental samples. Environmental and Chemical Physics, 22(3/4), 117-125.

6. Konikow L.F., Goode D.J., Hornberger G.Z. (1996) A three-dimentional method-ogcharacteristics solute-transport model (MOC3D). U.S.Geological Survey, Water-resources investigation report 96-4267, Reston, Virginia, USA

7. Mažeika J., Petrošius R., Jakimavičiūtè-Maselienè V., Butkus D., Konstantinova M., Remeikis V., Baltrūnas D. (2003) Evaluation of processes and parameters governing radionuclide transfer in hydrogeological systems, Environmental and Chemical Physics, 22(1/2), 191-201.

8. Clavensjo A., Akerblom G. and Morkūnas G. (1999) Radon indoors, and methods of its amount decrease, Vilnius, 128 (in Lithuanian).

9. Butkus D., Lebedytè M., Lubytè G., Matusevičius K. and Mažeika J. (2001) ${ }^{137} \mathrm{Cs}$ and ${ }^{90} \mathrm{Sr}$ in the soils of Lithuania, Geochemistry international, 39(7), 719-724.

10. Butkus D. and Konstantinova M. (2003) Studies of long-term vertical migration of ${ }^{137} \mathrm{Cs}$ in soil, Environmental and Chemical Physics, 25(2), 75-80. 